\title{
Effects of Rock Fragments on the Soil Physicochemical Properties and Vegetation on the Northeastern Tibetan Plateau
}

\section{OPEN ACCESS}

Edited by:

Rossano Ciampalini, Agrosup Dijon, France

Reviewed by:

Jian Sun,

Institute of Tibetan Plateau Research

(CAS), China

Xiuqing Nie,

Chinese Academy of Forestry, China

D. G. Rossiter,

Cornell University, United States

${ }^{*}$ Correspondence:

Changming Zhao

zhaochm@|zu.edu.cn

Specialty section:

This article was submitted to

Soil Processes,

a section of the journal

Frontiers in Environmental Science

Received: 14 April 2021

Accepted: 01 June 2021

Published: 21 June 2021

Citation:

Zheng Y, Chen N, Zhang C, Dong $X$ and Zhao C (2021) Effects of Rock

Fragments on the Soil

Physicochemical Properties and

Vegetation on the Northeastern

Tibetan Plateau.

Front. Environ. Sci. 9:693769.

doi: 10.3389/fenvs.2021.693769

\author{
Ying Zheng ${ }^{1,2}$, Ning Chen ${ }^{1,2}$, Cankun Zhang ${ }^{1,2}$, Xiaoxue Dong ${ }^{1,2}$ and Changming Zhao ${ }^{1,2 *}$ \\ ${ }^{1}$ State Key Laboratory of Grassland Agro-ecosystems, School of Life Sciences, Lanzhou University, Lanzhou, China, ${ }^{2}$ Yuzhong \\ Mountain Ecosystem Field Observation and Research Station, Lanzhou University, Lanzhou, China
}

Stony soils are very widely distributed and contain abundant rock fragments ( $>2 \mathrm{~mm}$ ), which impose major effects on soil properties and plant growth. However, the role of rock fragments is still often neglected, which can lead to an inadequate understanding of the interaction between plants and soil. Undisturbed soil columns were collected from three alpine grasslands on the Qilian Mountain, and the X-ray computed tomography method was applied to investigate the characteristics of rock fragments. The results showed there was significant difference in number density, volumetric content and surface area density of rock fragment among the three grasslands, and followed the order of alpine meadow > alpine steppe > alpine desert steppe. In addition, the soil organic carbon, total nitrogen, total phosphorus, available phosphorus, $\mathrm{N}-\mathrm{NH}_{4}{ }^{+}$, and $\mathrm{N}-\mathrm{NO}_{3}{ }^{-}$contents in fine earth all increased with increasing number density, volumetric content and surface area density but to different degrees. Furthermore, positive correlations were observed between the rock shape factor and belowground biomass $\left(R^{2}=0.531, p<0.05\right)$, between the rock volumetric content and aboveground biomass $\left(R^{2}=0.527, p<0.05\right)$, and between number density and Simpson's index $\left(R^{2}=0.875, p<0.05\right)$. Our findings suggest that within a certain range, the increase in rock fragment content is conducive to soil nutrient accumulation and soil water storage and circulation and changes plant features, which contributes to the growth of plants. In addition, rock fragments should be given more consideration when investigating the relationships between soil and vegetation and their response to climate change in future studies.

Keywords: stony soil, rock fragments, $\mathrm{X}$-ray $\mathrm{CT}$, tibetan plateau, alpine grassland

\section{INTRODUCTION}

Stony soils differ from non-stony soils by the substantial content of rock fragments (soil mineral particles larger than $2 \mathrm{~mm}$ in diameter, including gravels, cobbles, stones, and boulders), and widely distributed across global terrestrial ecosystems (Novák and Hlaváčiková, 2019). Stony soils contain abundant rock fragments as a result of both natural soil forming processes and human activities, and the presence of the two qualitatively different components of stony soil (fine earth and rock fragments) creates a heterogeneous soil structure (Zhang et al., 2016a). Stony soils are very widely distributed worldwide and occur in many forested, mountainous and even agricultural regions. For example, approximately $30 \%$ of the areas in Western Europe and up to $60 \%$ of Mediterranean are 
covered with stony soils (Poesen and Lavee, 1994), and soils with a high rock fragment content also cover $18 \%$ of the land surface of China (Ma and Shao, 2008). Especially, soils are typically characterized by the presence of rock fragments in most areas, such as the Qinghai-Tibetan Plateau (Qin et al., 2015) and karst regions (Shen et al., 2020). Despite the widespread occurrence of rock fragments in soils, little attention has been paid to their ecological and environmental effects.

It is known that rock fragments impose major effects on hydrological processes and soil physicochemical properties (Poesen and Lavee, 1994; Zhang et al., 2016b). The spatial distribution, size, shape, weathering degree, and quantity of the rock fragments in the soil profile significantly regulate water retention, infiltration and gas exchange processes, and increase the complexity of soil hydraulic properties and also influence the soil organic carbon, nutrient dynamics, and susceptibility to erosion (Sauer and Logsdon, 2002; Zhou et al., 2011; Rabot et al., 2018; Ceacero et al., 2020). In addition, rock fragments regulate plant root systems and influence plant growth (De Baets et al., 2007; Estrada-Medina et al., 2013). However, the attention and interest of pedologists and ecologists are mainly focused on the fine soil properties in stony soil, and often ignore the impact of rock debris on soil physicochemical properties and plant growth. As a result, this may lead to an inadequate understanding of soil properties and interaction between plants and soil (Hlaváciková et al., 2015; Comino et al., 2017; Ilek et al., 2019).

Recently, more attention has been paid to the rock fragments in stony soils (Chen et al., 2011; Ceacero et al., 2012; Du et al., 2017; Hlaváčiková et al., 2019). For example, Tetegan et al. (2015) demonstrated that the rock fragments in soil could act as water reservoirs for plants, and as mulch, rock fragments contributed to evaporation reduction. The effects of rock fragments on soil hydraulic properties are inconsistent under different climatic and specific soil conditions, either revealing reduced infiltration and increased runoff or the opposite effects (Tetegan et al., 2012; Ceacero et al., 2020). However, great difficulties remain in the determination of rock fragment characteristics, includs the type, fraction, size, spatial distribution and porosity (Coppola et al., 2013), and few studies have investigated changes in these features, especially in alpine ecosystems (Mi et al., 2016).

Methods of testing stony soils are constantly being developed, which may help with the former conundrum. At first, due to the limitation of sampling and analysis methods of stony soil, the representative element volume theory at that time recommend the separate measurement of the properties of the rock fragment and fine earth fractions of stony soils (Novák and Hlaváčiková, 2019). After that, combined tracers of dye and iodine (Wang and Zhang, 2011), tension infiltrometers (Zhang et al., 2016a), numerical estimations (Hlaváčiková et al., 2016), and field spatial electrical resistivity measurements are commonly used (Tetegan et al., 2012). In recent years, with the development of scanning technology, X-ray computed tomography (CT) imaging techniques have become more widely used in soil research and are excellent direct, quantitative and visual evaluation methods of soil morphological and topological descriptors from 3D images without damaging the soil structure (Wildenschild and Sheppard, 2013; Helliwell et al., 2014; Callow et al., 2018; Reyes et al., 2018).

Tibetan alpine grassland is one of the most sensitive and vulnerable ecosystems to regional climate change and human activities (Xu et al., 2010; Nie et al., 2021). Alpine grassland soil exhibits distinct stony characteristics, and rock fragments of different sizes widely occur (Qin et al., 2015). However, studies concerning the interactions among rock fragments and soil physicochemical properties and alpine vegetation growth are rare, particularly for the alpine ecosystems on the Tibetan Plateau. More efforts are required to examine rock fragments to determine their possible influence on soil physicochemical properties and plant growth and to assess their ecological function in maintaining the sustainable development of the natural grassland ecosystems on the Tibetan Plateau. We hypothesized that 1) the soil rock fragments will differ among the three grassland types on the Qinghai-Tibet Plateau; and 2) these differences indirectly affect the growth of vegetation through changes in soil physical and chemical properties. Therefore, the objective of this study was to apply CT imaging techniques to quantify the rock fragment features of three types of alpine grasslands on the northeastern Tibetan Plateau and provide a better understanding of the interaction between the soil properties and plant growth.

\section{MATERIALS AND METHODS}

\section{Study Sites}

This study was conducted on the northeastern edge of the Tibetan Plateau in the Tianzhu alpine grassland $\left(37^{\circ} 17^{\prime} \mathrm{N}, 102^{\circ} 43^{\prime} \mathrm{E}\right)$ in Gansu Province, China. The mean annual temperature is $-0.1^{\circ} \mathrm{C}$, ranging from $-18.3^{\circ} \mathrm{C}$ in January to $12.7^{\circ} \mathrm{C}$ in July, and the average annual precipitation is $425 \mathrm{~mm}$, while approximately $70-80 \%$ of the annual precipitation occurs in July, August, and September (Wang et al., 2019). This region is characterized by a long and cold winter, as well as a short and mild summer, which is a typical continental plateau climate. The plant growth period lasts approximately 120-140 days ( $\mathrm{Li}$ et al., 2017).

In July 2019, we designed a set of field measurements based primarily on our previous vegetation sampling sites. In previous studies, differences in vegetation traits (aboveground biomass (AGB), number of species, and cover) reflecting the vegetation conditions across Tianzhu County were obtained (Yunfei et al., 2019). The dominant steppe types include alpine steppe, alpine meadow, and alpine desert steppe. We selected three sites as sampling areas in each steppe type. Landscapes of the three steppe types are shown in Figure 1. At Site 1, the main species were Stipa capillata L., Artemisia frigida Willd., and Euphorbia fischeriana Steud. At Site 2, the main species were Potentilla bifurca L., Kobresia myosuroides (Villars) Fiori, and Carex moorcroftii. At Site 3, the main species were Agropyron cristatum (L.) Gaertn., Achnatherum splendens (Trin.) Nevski, and Stipa capillata L. These sites were chosen with similar aspect and topography conditions, and the vegetation at these sites was prolific. The specific sampling site information is listed in Table $\mathbf{1}$ 


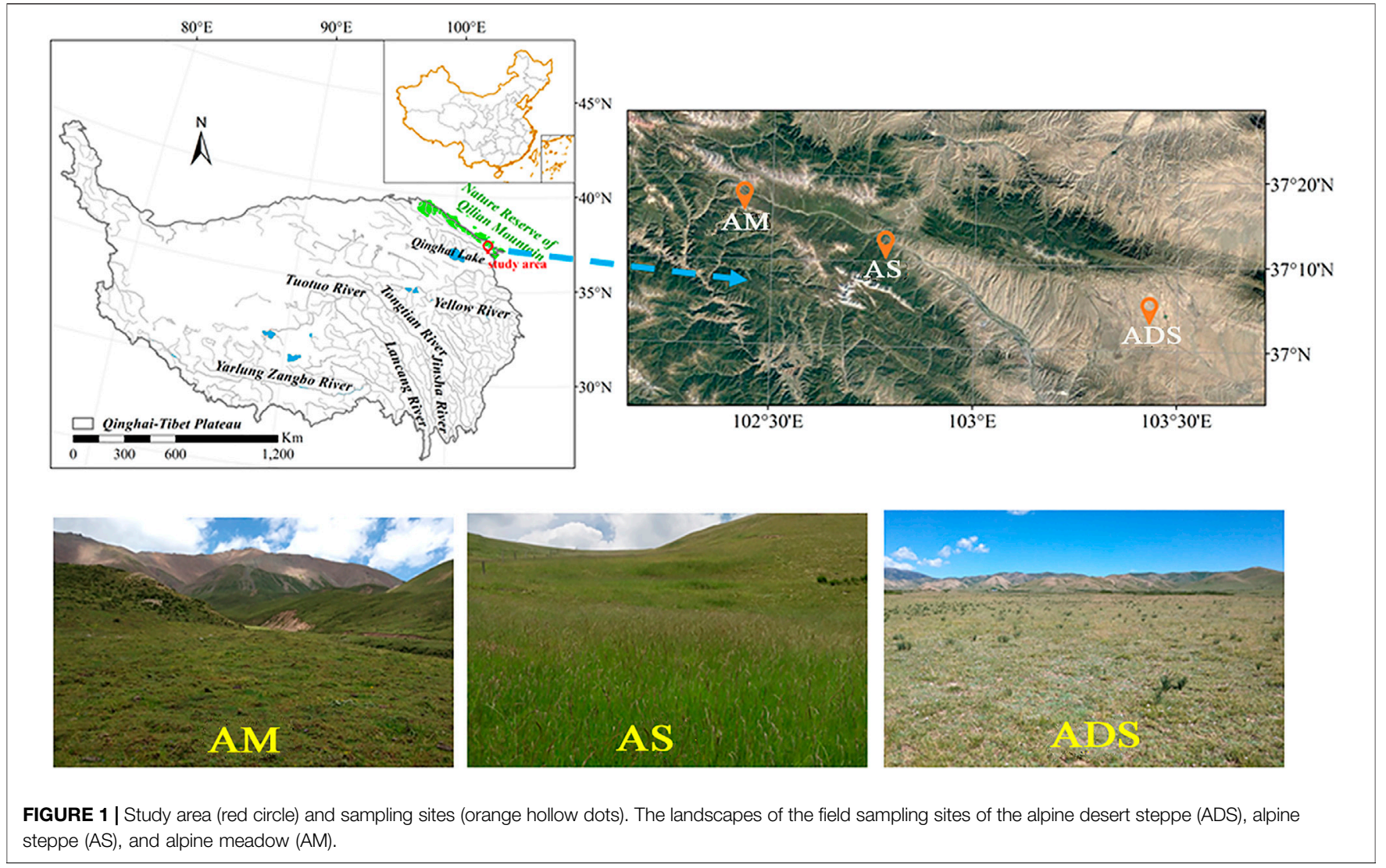

TABLE 1 | Site information under three vegetation types.

\begin{tabular}{|c|c|c|c|c|c|c|c|c|}
\hline Types & Latitude/ ${ }^{\circ} \mathbf{N}$ & Longitude $/^{\circ} \mathrm{E}$ & Elevation/m & Administrative region & Soil layer/cm & Slope position & Aspect & Gradient/ ${ }^{\circ}$ \\
\hline ADS & 37.08 & 103.43 & 2,675 & Tianzhu county & $0-30$ & Middle & Southeast & 4 \\
\hline AS & 37.20 & 102.78 & 2,858 & Tianzhu county & $0-30$ & Middle & Southeast & 6 \\
\hline AM & 37.29 & 102.43 & 3,641 & Tianzhu county & $0-20$ & Middle & Southeast & 10 \\
\hline
\end{tabular}

Vegetation Investigation and Soil Sampling At each sampling site, three $50 \times 50 \mathrm{~cm}$ quadrats were established, and the abundance plant species was investigated, which was used to calculate the plant diversity (Simpson's index). The aboveground parts of plant were cut off along the ground to calculate the aboveground biomass (AGB), and the soil profile was determined below the quadrat to measure the belowground biomass (BGB) in the depth range from 0 to $30 \mathrm{~cm}$. The aboveground and underground parts of all species in each quadrat were harvested and oven dried at $65^{\circ} \mathrm{C}$ for $48 \mathrm{~h}$ to determine the $\mathrm{AGB}$ and $\mathrm{BGB}$ respectively. The data for three quadrats were averaged to describe each site.

To investigate the 3-D characteristics of rock fragment, soil samples were collected at depths from 0 to $30 \mathrm{~cm}$ for ADS and AS and at depths from 0 to $20 \mathrm{~cm}$ for AM (because the rock fragment content in the AM soil was very high, and only $0-20 \mathrm{~cm}$ soil columns could be obtained). The soil column sampling plots are distributed around the vegetation survey quadrats, $50 \mathrm{~cm}$ apart from the vegetation survey quadrats. Nine intact soil columns were collected at the three sites, with three replicates per site. Polyvinyl chloride (PVC) cylinders (with $3-\mathrm{mm}$ thick walls, $11 \mathrm{~cm}$ in diameter, and $30 \mathrm{~cm}$ in length) with a beveled bottom edge were used to house the soil columns. Shrubs and grasses were carefully clipped and removed to the ground level under minimal disturbance before original soil column sampling. The soil column extraction followed the procedure of Sammartino et al. (2012). The soil columns were sealed with gauze and plastic film, wrapped with sponge and packed with wheat straw, and carefully transported to avoid any compaction and evaporation. In addition, on the profile generated after 
sampling of each soil column, three replicate soil samples $(0-10,10-20$, and $20-30 \mathrm{~cm})$ were collected to analyze soil physicochemical properties. Undisturbed $100-\mathrm{cm}^{3}$ soil cores (50.46 $\mathrm{mm}$ in diameter and $50 \mathrm{~mm}$ in height) with three replicates were collected from each soil layer.

\section{Analysis of the Soil Samples}

The undisturbed soil cores were oven dried at $105^{\circ} \mathrm{C}$ for $48 \mathrm{~h}$ to measure the soil bulk density (BD) based on the dry weight of each core (Wilson et al., 2013). The total porosity was calculated as (1-BD/ particle density) $\times 100$ (Allen et al., 2007). Generally, the particle density of most soils is $2.65 \mathrm{~g} \mathrm{~cm}^{-3}$ (Zhen et al., 2017), which was used in our calculations. The field water holding capacity (FC) was also measured by the undisturbed soil cores using cutting-ring method (Zhen et al., 2017). The soil samples were air dried at room temperature before sieving through $2 \mathrm{~mm}$ sieves for analysis of the soil particle distribution. The soil particle size distribution was determined with a laser particle size meter (Mastersizer 2000; Malvern), and the grading standards for the soil particle size fraction were retrieved from the United States Department of Agriculture (Zhen et al., 2017). For the determination of the soil organic carbon (SOC), total nitrogen (TN), total phosphorus (TP), total potassium (TK) and the contents of other available nutrients, subsamples were air dried and ground to pass through a $0.15-\mathrm{mm}$ mesh to remove any roots, rocks, and woody debris. The SOC content was measured by the dichromate oxidation method, and TN was measured with the dry combustion method (Vario MACRO cube, Elementar, Germany). The soil inorganic nitrogen $\left(\mathrm{N}-\mathrm{NH}_{4}{ }^{+}\right.$ and $\mathrm{N}-\mathrm{NO}_{3}{ }^{-}$) was measured using the $\mathrm{KCL}$ extraction procedure, the TP concentration was measured through the colorimetric method with ammonium molybdate-vanadate as the coloring reagent (Jackson, 2005), and the available phosphorus (AP) concentration was measured with the $\mathrm{NaHCO}_{3}$ extraction procedure and the same colorimetric method as was adopted for phosphorus. These concentrations $\left(\mathrm{g} \mathrm{kg}^{-1}\right)$ were measured using an Auto-Discrete Analyzer System (Smartchem140, AM, Italy). The soil was digested with $\mathrm{HF}-\mathrm{HClO}_{4}-\mathrm{H}_{2} \mathrm{SO}_{4}$ for the determination of TK (Bhattacharyya et al., 2006), and the available or labile potassium (AK) was extracted with $\mathrm{NH}_{4} \mathrm{OAc}$ (Islam et al., 2017), while the potassium in the aliquots was determined with an atomic absorption spectrophotometer (2655-00, Cole-Parmer, IL, United States).

\section{Undisturbed Soil Sample Scanning by X-Ray CT and Data Processing}

The soil columns were scanned with a helical medical CT instrument (SOMATOM Definition Flash, SIEMENS, Germany) at an excitation voltage of $140 \mathrm{kV}$ at $300 \mathrm{~mA}$ in the First Hospital of Lanzhou University. The scan resolution was $0.236 \mathrm{~mm}$ horizontally and $0.600 \mathrm{~mm}$ vertically. The produced scanning images of $512 \times 512$ pixels per slice had a voxel dimension of $0.236 \mathrm{~mm} \times 0.236 \mathrm{~mm} \times 0.6 \mathrm{~mm}$ in each reconstructed image. Each column was vertically scanned, and more than 500 slices were generated, while invalid top and bottom images were removed. Approximately 500 images were analyzed in the subsequent analysis.
Avizo 9.0 (FEI, 2015) software was employed for all of the image processing and parameter calculation steps of the CT images. First, the images were processed to exclude the area outside the soil column, and all the images were carefully examined to determine whether any soil columns might exhibit a distinctly unnatural macropore morphology caused by sampling. The edge of each soil column was cut to eliminate any possible sampling interference along the edge. After comprehensive observation and consideration, the diameter was reduced to $90 \mathrm{~mm}$, and a cylindrical cropping tool was applied to obtain the region of interest (ROI). Second, to improve the image quality, a median filter (radius of 3.0 pixels, a commonly used image processing method) was implemented to minimize the noise from all the reconstructed volumes. We used a plexiglas cylinder was inserted into a soil core, then take it out and measure its diameter with a digital caliper, and scanned it using a helical medical CT device. Then we assumed an initial threshold to calculate the macropore size when using the avizo 2019 software, and compared the calculation result with the measured size obtained with a digital caliper. If the difference between the calculated and measured sizes is significant, another threshold is given to continue the calculation, so that the difference is less than 1\% (Li et al., 2013; Hu et al., 2016).

After segmentation, the rock fragment networks were reconstructed, and the $3 \mathrm{D}$ distribution along the column depth and the size distribution (sorted by the volume) were visualized. We adopted the equivalent diameter $(d e)$ to represent the size of the rock fragments according to the equivalent diameter grades (Figure 2). The rock fragments were divided into four categories and assigned different colors: $2<d e<4 \mathrm{~mm}$ (blue), $4<d e<6 \mathrm{~mm}$ (red), $6<d e<10 \mathrm{~mm}$ (green), and $10<d e<25 \mathrm{~mm}$ (yellow) (Poesen and Lavee, 1994; Chen et al., 2011; Novák and Hlaváčiková, 2019). The number, surface area, volume, shape factor (SF) and equivalent diameter of the rock fragments were calculated. The selection and determination methods of the quantitative parameters of the rock characteristics are as follows:

(a) Number density (ND), the number of rock fragments in a given volume, can reflect the distribution of the stone rock fragments.

(b) Equivalent diameter $\left(d_{e}\right)$, the equivalent diameter is the diameter of a sphere of the same volume.

$$
d_{e}=\sqrt[3]{\frac{6 \times \text { Volume }}{\pi}}
$$

(c) Surface area (SA), area of the rock fragment boundary.

(d) Volume $(V)$, volume of the rock fragments.

(e) Shape factor $(S F)$, the $S F$ is a parameter that describes the shape of an object, which equals 1 for a perfect sphere.

$$
S F=\frac{S A^{3}}{36 \times \pi \times V^{2}}
$$

\section{Statistical Analysis}

One-way ANOVA was conducted to analyze the differences in rock fragment features among the three sites, and the least- 

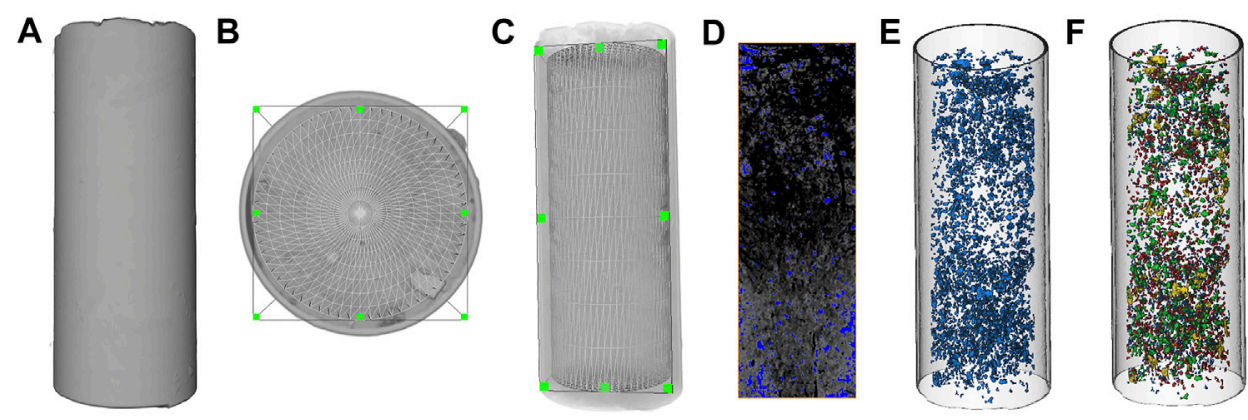

FIGURE 2 | Process steps of the scanned images of the soil columns using Avizo 9.0 software: 3D imaging of the original soil column (A), top view (B) and lateral view (C) of the region of interest (ROI) (cylinder), cross-section of interactive thresholding segmentation (blue indicates the selected rock fragment) (D), 3D reconstruction of the rock fragment network $(\mathbf{E})$, and assignment of different colors for the different equivalent diameter grades of the rock fragments (F).
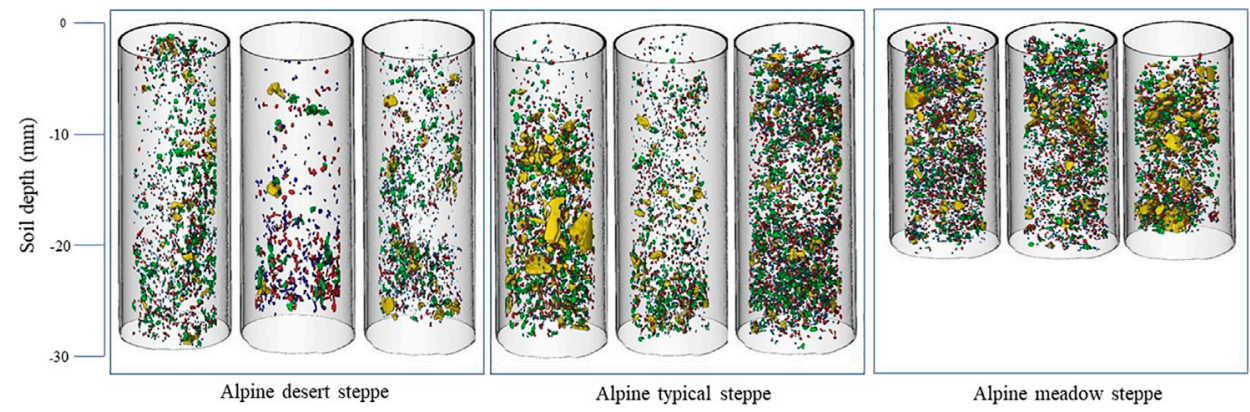

FIGURE 3 | 3-D visualization of rock fragments networks in the soil columns under alpine desert steppe (ADS), alpine steppe (AS), and alpine meadow (AM).

significant difference (LSD) post hoc test $(p<0.05)$ was performed to compare the rock fragment characteristics among the three grassland types. Before analysis, the data were transformed into normal by arcsine method to conform to the normal hypothesis of ANOVA. Principal component analysis (PCA) was conducted to reveal the relation between the rock fragment features and soil physiochemical properties of the different grassland types. Finally, stepwise regression was implemented to test the relationship between the rock fragments and plant growth. Stepwise regression can be adopted to filter any independent variables with multicollinearity, in which the independent variables with high explanation degrees of the dependent variables are retained, while those with low explanation degrees are excluded from the model. And the variance inflation factors (VIF) method was used to test the multicollinearity in stepwise variable selection (Zhang et al., 2020). Hence, linear regression was used to analyze the relationship between the retained independent variables and the dependent variables. One-way ANOVA and stepwise regression analysis were conducted using software program SPSS (version 20, IBM Corporation, NY, United States). PCA and graphing were performed with Canoco (version 5.0, Microcomputer Power Corporation, NY, United States), and regression analysis graphs were generated with Origin software (version 9.0, OriginLab Corporation, MA, United States).

\section{RESULTS}

\section{Visualization of the Rock Fragment Networks and Rock Fragment Characteristics}

It is clear that the spatial distribution of the rock fragments was distinctly different among the soils for the different grassland types (Table 2, Figure 3). The 2-6 mm rock fragments comprised the largest fraction of rock fragments in the different soil layers of all three vegetation types. Large numbers of large stones occurred in the soil column of AM, and the rock fragments distributed in the surface soil $(0-10 \mathrm{~cm})$ of AM were far more abundant than those in the surface soils of ADS and AS. The rock fragments were more evenly distributed and less heterogeneous in the soil column of AM than those in the soil columns of ADS and AS. The number of rock fragments and proportion of large rocks increased in ADS and AS with increasing soil depth, while there was no significant increase in AM.

There was no significant difference in mean shape factor and equivalent diameter the three grassland types. The number density of the rock fragments in the $0-30 \mathrm{~cm}$ soil layer were ordered as $\mathrm{AM}>\mathrm{AS}>\mathrm{ADS}$, and $\mathrm{ND}(1,310 \pm 171)$ in $\mathrm{AM}$ (0-20 cm) was approximately 4.9 times larger than that in ADS $(0-20 \mathrm{~cm}, 266 \pm 64)$. The volumetric content and surface area 
TABLE 2 | Rock fragments characteristics under three vegetation types.

\begin{tabular}{|c|c|c|c|c|c|c|}
\hline Types & Soil layer/cm & ND (no. $\mathrm{mm}^{-3}$ ) & VC (\%) & SAD (\%) & SF & $M d_{e}(m m)$ \\
\hline \multirow[t]{4}{*}{ ADS } & $0-10$ & $0.21 \pm 0.06 \mathrm{a}$ & $0.50 \pm 0.07 \mathrm{a}$ & $0.01 \pm 0.00 \mathrm{a}$ & $2.15 \pm 0.35 a$ & $3.05 \pm 0.17 a$ \\
\hline & 10-20 & $0.34 \pm 0.07 a$ & $0.71 \pm 0.12 \mathrm{a}$ & $0.01 \pm 0.00 \mathrm{a}$ & $1.94 \pm 0.11 \mathrm{a}$ & $2.95 \pm 0.03 a$ \\
\hline & $20-30$ & $0.55 \pm 0.06 \mathrm{a}$ & $1.18 \pm 0.04 \mathrm{a}$ & $0.03 \pm 0.00 \mathrm{a}$ & $2.54 \pm 0.16 a$ & $3.01 \pm 0.05 a$ \\
\hline & 0-30 & $0.37 \pm 0.06 \mathrm{a}$ & $0.80 \pm 0.07 \mathrm{a}$ & $0.02 \pm 0.01 \mathrm{a}$ & $2.28 \pm 0.13 a$ & $2.99 \pm 0.04 a$ \\
\hline \multirow[t]{4}{*}{ AS } & $0-10$ & $0.99 \pm 0.32 b$ & $1.56 \pm 0.50 \mathrm{a}$ & $0.04 \pm 0.02 \mathrm{a}$ & $2.26 \pm 0.77 \mathrm{a}$ & $2.71 \pm 0.32 a$ \\
\hline & 10-20 & $1.08 \pm 0.25 a$ & $3.11 \pm 1.27 \mathrm{ab}$ & $0.05 \pm 0.01 \mathrm{a}$ & $1.81 \pm 0.18 \mathrm{a}$ & $3.11 \pm 0.19 a$ \\
\hline & $20-30$ & $1.49 \pm 0.29 b$ & $4.86 \pm 1.62 b$ & $0.08 \pm 0.01 b$ & $2.30 \pm 0.29 a$ & $3.16 \pm 0.19 a$ \\
\hline & $0-30$ & $1.11 \pm 0.29 b$ & $3.17 \pm 0.95 a$ & $0.05 \pm 0.01 \mathrm{a}$ & $2.20 \pm 0.37 a$ & $3.11 \pm 0.17 \mathrm{a}$ \\
\hline \multirow[t]{3}{*}{ AM } & $0-10$ & $2.08 \pm 0.30 c$ & $6.95 \pm 0.33 b$ & $0.10 \pm 0.00 \mathrm{~b}$ & $2.07 \pm 0.18 a$ & $3.04 \pm 0.13 a$ \\
\hline & 10-20 & $2.18 \pm 0.30 b$ & $6.10 \pm 1.51 b$ & $0.09 \pm 0.01 b$ & $2.00 \pm 0.07 a$ & $2.92 \pm 0.09 a$ \\
\hline & $0-20$ & $2.13 \pm 0.27 c$ & $6.53 \pm 0.76 b$ & $0.10 \pm 0.00 \mathrm{~b}$ & $2.04 \pm 0.13 a$ & $2.98 \pm 0.10 a$ \\
\hline
\end{tabular}

All data were expressed as means \pm standard errors (SE) of the mean. SF, shape factor; $M d_{e}$, equivalent diameter; ND, number density; VC, the volumetric content of rock fragments; SAD, surface area density. Different lowercase letters indicate significant differences between two vegetation types at the same soil layer ( $p<0.05)$.

\begin{tabular}{|c|c|c|c|c|c|c|c|}
\hline \multirow[t]{2}{*}{ Types } & \multirow[t]{2}{*}{ Depth (cm) } & \multicolumn{3}{|c|}{ Particle size distribution (\%) } & \multirow{2}{*}{$\begin{array}{c}\text { BD } \\
\left(\mathrm{g} \mathrm{cm}^{-3}\right)\end{array}$} & \multirow[t]{2}{*}{$\mathrm{SP}\left(\mathrm{cm}^{3} \mathrm{~cm}^{-3}\right)$} & \multirow[t]{2}{*}{ FC (\%) } \\
\hline & & Sand $(0.05-2.00 \mathrm{~mm})$ & Silt $(0.002-0.05 \mathrm{~mm})$ & Clay $(<0.002 \mathrm{~mm})$ & & & \\
\hline \multirow[t]{4}{*}{ ADS } & $0-10$ & $15.92 \pm 2.10 \mathrm{a}$ & $75.17 \pm 2.34 \mathrm{a}$ & $8.90 \pm 0.47 a$ & $1.13 \pm 0.02 \mathrm{a}$ & $52.12 \pm 5.42 \mathrm{a}$ & $42.18 \pm 0.47 a$ \\
\hline & $10-20$ & $13.89 \pm 1.22 \mathrm{a}$ & $76.11 \pm 1.41 \mathrm{a}$ & $10.00 \pm 0.23 a$ & $1.11 \pm 0.04 \mathrm{a}$ & $55.52 \pm 14.53 a$ & $42.80 \pm 6.73 a$ \\
\hline & 20-30 & $13.55 \pm 2.67 \mathrm{a}$ & $77.85 \pm 3.59 \mathrm{a}$ & $8.61 \pm 1.70 \mathrm{a}$ & $1.00 \pm 0.01 \mathrm{a}$ & $52.87 \pm 8.34 \mathrm{a}$ & $52.16 \pm 3.30 \mathrm{a}$ \\
\hline & $0-30$ & $14.45 \pm 1.77 \mathrm{a}$ & $76.38 \pm 2.46 \mathrm{a}$ & $9.17 \pm 0.68 \mathrm{a}$ & $1.08 \pm 0.02 \mathrm{a}$ & $53.50 \pm 6.93 a$ & $45.71 \pm 2.86 a$ \\
\hline \multirow[t]{4}{*}{ AS } & $0-10$ & $11.58 \pm 0.48 a$ & $79.33 \pm 0.38 a$ & $9.09 \pm 0.28 a$ & $1.05 \pm 0.03 a$ & $43.09 \pm 7.13 b$ & $47.39 \pm 4.81 \mathrm{a}$ \\
\hline & $10-20$ & $14.36 \pm 1.78 \mathrm{a}$ & $76.85 \pm 1.52 \mathrm{a}$ & $8.79 \pm 0.33 a$ & $1.07 \pm 0.08 \mathrm{ab}$ & $42.94 \pm 9.52 b$ & $46.60 \pm 7.96 a$ \\
\hline & $20-30$ & $12.28 \pm 1.39 a$ & $76.10 \pm 3.09 a$ & $11.62 \pm 1.80 \mathrm{a}$ & $1.02 \pm 0.06 \mathrm{a}$ & $54.79 \pm 2.85 a$ & $53.56 \pm 3.17 \mathrm{a}$ \\
\hline & $0-30$ & $12.74 \pm 1.48 \mathrm{a}$ & $77.43 \pm 2.57 \mathrm{a}$ & $9.83 \pm 0.49 a$ & $1.05 \pm 0.03 a$ & $46.94 \pm 7.42 b$ & $49.18 \pm 4.33 a$ \\
\hline \multirow[t]{4}{*}{ AM } & $0-10$ & $11.26 \pm 1.38 a$ & $79.20 \pm 1.24 \mathrm{a}$ & $9.54 \pm 0.37 a$ & $0.97 \pm 0.09 a$ & $50.85 \pm 2.78 a$ & $50.54 \pm 7.28 a$ \\
\hline & $10-20$ & $13.46 \pm 1.31 \mathrm{a}$ & $76.45 \pm 2.04 \mathrm{a}$ & $10.09 \pm 0.95 a$ & $0.91 \pm 0.06 b$ & $57.90 \pm 4.20 a$ & $58.28 \pm 3.80 b$ \\
\hline & $20-30$ & $12.86 \pm 2.13 a$ & $77.01 \pm 2.48 \mathrm{a}$ & $10.13 \pm 0.60 a$ & $0.95 \pm 0.09 a$ & $56.09 \pm 6.80 a$ & $60.49 \pm 12.84 b$ \\
\hline & $0-30$ & $12.49 \pm 1.62 \mathrm{a}$ & $77.55 \pm 2.31 \mathrm{a}$ & $9.92 \pm 0.52 \mathrm{a}$ & $0.94 \pm 0.06 b$ & $54.95 \pm 4.31 \mathrm{a}$ & $56.44 \pm 3.44 b$ \\
\hline
\end{tabular}

All data were expressed as means \pm standard errors (SE) of the mean. Different lowercase letters indicate significant differences between two vegetation types at the same soil layer $(p<0.05)$. BD, SP, and FC are abbreviations of bulk density, soil porosity and field capacity respectively.

TABLE 4 | Chemical properties of soil under three vegetation types.

\begin{tabular}{|c|c|c|c|c|c|c|c|c|c|}
\hline Types & $\begin{array}{c}\text { Depth } \\
\text { (cm) }\end{array}$ & $\begin{array}{c}\text { SOC } \\
\left(g^{\left.k g^{-1}\right)}\right.\end{array}$ & $\begin{array}{c}\mathrm{TN} \\
\left(\mathrm{g} \mathrm{kg}^{-1}\right)\end{array}$ & $\begin{array}{l}\mathrm{N}-\mathrm{NH}_{4}^{+} \\
\left(\mathrm{g} \mathrm{kg}^{-1}\right)\end{array}$ & $\begin{array}{l}\mathrm{N}-\mathrm{NO}_{3}^{-} \\
\left(\mathrm{g} \mathrm{kg}^{-1}\right)\end{array}$ & $\begin{array}{c}\text { TP } \\
\left(g_{k g}^{-1}\right)\end{array}$ & $\begin{array}{c}\text { AP } \\
\left(g^{-1}\right)\end{array}$ & $\begin{array}{c}\text { TK } \\
\left(\mathrm{g} \mathrm{kg}^{-1}\right)\end{array}$ & $\begin{array}{c}A K \\
\left(g_{k g}^{-1}\right)\end{array}$ \\
\hline \multirow[t]{4}{*}{ ADS } & $0-10$ & $22.59 \pm 0.87 a$ & $2.27 \pm 0.12 \mathrm{a}$ & $0.0054 \pm 0.00 a$ & $0.0077 \pm 0.00 \mathrm{a}$ & $0.59 \pm 0.05 a$ & $0.0015 \pm 0.00 \mathrm{a}$ & $5.43 \pm 0.15 a$ & $0.09 \pm 0.00 a b$ \\
\hline & $10-20$ & $18.51 \pm 1.73 \mathrm{a}$ & $2.10 \pm 0.17 \mathrm{a}$ & $0.0035 \pm 0.00 \mathrm{a}$ & $0.0039 \pm 0.00 \mathrm{a}$ & $0.62 \pm 0.02 \mathrm{a}$ & $0.0009 \pm 0.00 \mathrm{a}$ & $5.57 \pm 0.20 a b$ & $0.08 \pm 0.00 \mathrm{a}$ \\
\hline & $20-30$ & $15.32 \pm 2.43 a$ & $2.00 \pm 0.21 \mathrm{a}$ & $0.0022 \pm 0.00 a$ & $0.0041 \pm 0.00 a$ & $0.63 \pm 0.03 a$ & $0.0007 \pm 0.00 a$ & $5.65 \pm 0.19 a$ & $0.08 \pm$ \\
\hline & & $18.81 \pm 2.31 \mathrm{a}$ & $2.12 \pm 0.14 \mathrm{a}$ & $0.0037 \pm 0.00 \mathrm{a}$ & $0.0234 \pm 0.00 \mathrm{a}$ & $0.61 \pm 0.03 \mathrm{a}$ & $0.0010 \pm 0.00 \mathrm{a}$ & $8 \mathrm{a}$ & $00 \mathrm{a}$ \\
\hline \multirow[t]{4}{*}{ AS } & & $31.12 \pm 0.45 b$ & $3.43 \pm 0.09 b$ & & $0.0129 \pm 0.00 b$ & & & $5.98 \pm 0.08 b$ & $0.00 \mathrm{a}$ \\
\hline & & $22.36 \pm 0.64 \mathrm{a}$ & $3.30 \pm 0.04 b$ & $0.0068 \pm 0.00 \mathrm{a}$ & $0.0090 \pm 0.00 \mathrm{~b}$ & $0.55 \pm 0.04 \mathrm{a}$ & $0.0022 \pm 0.00 \mathrm{a}$ & $5.95 \pm 0.11 \mathrm{a}$ & $0.24 \mathrm{a}$ \\
\hline & $20-30$ & $16.57 \pm 0.48 a$ & $2.97 \pm 0.03 b$ & $0.0049 \pm 0.00 \mathrm{~b}$ & $0.0072 \pm 0.00 \mathrm{a}$ & $0.49 \pm 0.02 b$ & $0.0012 \pm 0.00 \mathrm{a}$ & $5.55 \pm 0.12 \mathrm{a}$ & $0.09 \pm$ \\
\hline & $0-30$ & $23.35 \pm 0.47 \mathrm{a}$ & $3.23 \pm 0.03 b$ & $0.0064 \pm 0.00 \mathrm{ab}$ & $0.0097 \pm 0.00 \mathrm{~b}$ & $0.55 \pm 0.02 \mathrm{a}$ & $0.0022 \pm 0.00 \mathrm{a}$ & $5.83 \pm 0.12 \mathrm{a}$ & $0.09 \pm 0.00 \mathrm{a}$ \\
\hline \multirow[t]{4}{*}{ AM } & $0-10$ & $69.13 \pm 14.52 c$ & $5.67 \pm 0.54 \mathrm{c}$ & $0.0200 \pm 0.00 \mathrm{a}$ & $0.0113 \pm 0.00 b$ & $1.46 \pm 0.02 b$ & $0.0159 \pm 0.00 b$ & $5.19 \pm 0.14 \mathrm{a}$ & $0.08 \pm 0.00 \mathrm{~b}$ \\
\hline & $10-20$ & $53.67 \pm 9.15 b$ & $5.101 \pm 0.52 c$ & $0.0044 \pm 0.00 a$ & $0.0104 \pm 0.00 b$ & $1.44 \pm 0.03 b$ & $0.0071 \pm 0.00 b$ & $5.35 \pm 0.06 b$ & $0.08 \pm 0.00 \mathrm{a}$ \\
\hline & 20-30 & $38.74 \pm 2.51 b$ & $4.57 \pm 0.24 \mathrm{c}$ & $0.0028 \pm 0.00 a b$ & $0.0070 \pm 0.00 \mathrm{a}$ & $1.44 \pm 0.06 c$ & $0.0056 \pm 0.00 b$ & $5.48 \pm 0.05 a$ & $0.09 \pm 0.00 \mathrm{a}$ \\
\hline & $0-30$ & $53.85 \pm 5.67 b$ & $5.11 \pm 0.39 c$ & $0.0091 \pm 0.00 \mathrm{~b}$ & $0.0096 \pm 0.00 \mathrm{~b}$ & $1.45 \pm 0.04 b$ & $0.0095 \pm 0.00 b$ & $5.34 \pm 0.07 a$ & $0.08 \pm 0.00 a$ \\
\hline
\end{tabular}

All data were expressed as means \pm standard errors (SE) of the mean. SOC, Soil organic carbon; TN, Total nitrogen; TP, Total phosphorus; AP, Available phosphorus; TK, Total potassium; $A K$, available potassium. Different lowercase letters indicate significant differences between two vegetation types at the same soil layer ( $p<0.05)$. 


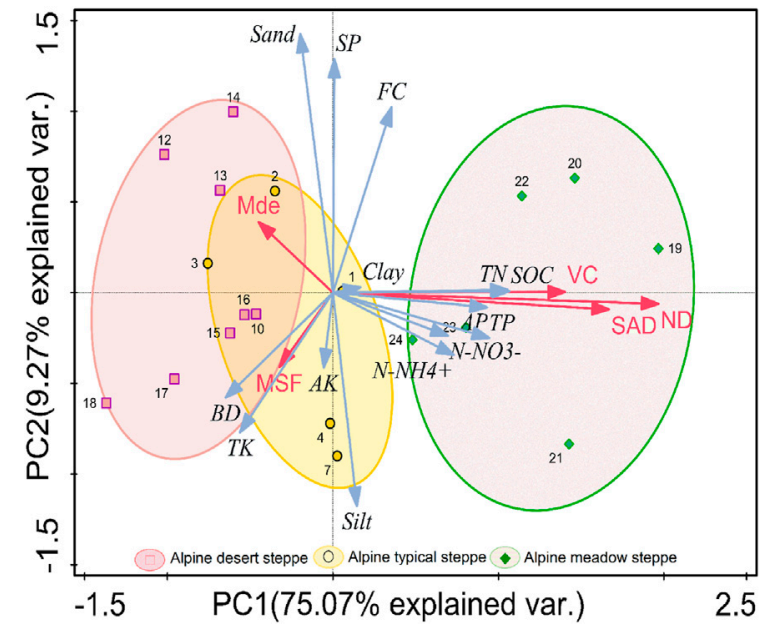

FIGURE 4 | Results of PCA analysis, which shows the relationship between the rock fragment characteristics and the soil variables. The red arrows indicate rock fragment parameters; the blue arrows indicate soil physiochemical properties.

density of the rock fragments in the $0-30 \mathrm{~cm}$ soil layer in AM were higher than those in ADS and AS.

\section{Properties of the Soil for the Different Vegetation Types}

A variance analysis of the soil properties of the $0-30 \mathrm{~cm}$ soil profile at three sites (ADS, AS, and AM) revealed the main differences between the locations (Tables 3, 4). The particle size distribution did not change significantly among the three sites. The soil bulk density is in the order of ADS > AS > AM, but the difference between ADS and AS is not significant. The difference in total porosity between ADS and AM is not significant, and both are higher than AS. The field water holding capacity of AM is higher than that of ADS and AS. The content of soil organic carbon and total nitrogen is different $(p<0.05$, Table 4), and in the order of AM $>$ AS $>$ ADS. In addition, the total phosphorus content of AM is much higher than ADS and AS, but there is no significant difference in the distribution of total potassium in the soil $(20 \sim 30 \mathrm{~cm})$, while the total potassium content in the $0 \sim 10$ and $10 \sim 20 \mathrm{~cm}$ soil layer AS is much higher than that of ADS and AM. In terms of the available nutrients, the $\mathrm{N}-\mathrm{NH}_{4}{ }^{+}$and $\mathrm{N}-\mathrm{NO}_{3}{ }^{-}$levels in AS and $\mathrm{AM}$ were much higher than those in ADS, and AP in AM was much higher than that in ADS and AS, while the difference in the distribution of soil AK in soil $(10 \sim 30 \mathrm{~cm})$ is not significant.

\section{Relationships Between the Rock Fragment Characteristics and Soil Properties}

PCA was conducted to verify the relationships between the rock fragment characteristics with respect to the soil properties (Figure 4). The results showed that the components of dimension $1(75.07 \%)$ and dimension 2 (9.27\%) accounted for
$84.34 \%$ of the explainable variance. The sites were grouped by the soil variables, and the biplots revealed a clear separation between the sites covered with the different vegetation types. The biplot of axis 1 was strongly correlated with number density, volumetric content and surface area density, and axis 2 was strongly correlated with shape factor and equivalent diameter.

There existed a significant positive correlation between three rock fragment characteristics (number density, volumetric content, surface area density) and soil nutrient content include soil organic carbon, total nitrogen, total phosphorous, available phosphorous and $\mathrm{N}-\mathrm{NH}_{4}{ }^{+}$and $\mathrm{N}-\mathrm{NO}_{3}{ }^{-}(p<0.001$, Figure 4). Meanwhile, number density, volumetric content, and surface area density were also significantly positively correlated with the field capacity $(p<0.05)$. in contrast, the three rock fragment characteristics exhibited a significantly negative relationship with bulk density ( $p<0.05$, Figure 4). A significant positive correlation occurred among mean equivalent diameter and soil total porosity $(p<0.001)$, sand content $(p<0.001)$, and field capacity $(p<0.05)$. in addition, shape factor was significantly positively correlated with bulk density and total potassium $(p<$ 0.001 ) and significantly negatively correlated with the total porosity $(p<0.001)$. The other soil variables were far removed from the rock fragment characteristics, indicating a low correspondence.

\section{Relationships Between the Rock Fragment Characteristics and the Vegetation Biomass and Diversity}

Stepwise regression analysis using the data from all study sites of the rock fragment characteristics was applied to determine the dominant rock fragment factors influencing the vegetation biomass (above and belowground biomass) and diversity (Simpson's index) among the three sites. Stepwise regression can eliminate the problem of collinearity among the rock fragment parameters, and only one parameter, the rock shape factor, was entered in the model that affected the belowground biomass of each grassland type community (Figure $\mathbf{5 A}, R^{2}=$ $0.531, p<0.05)$. Similarly, we also found that the rock volumetric content imposed the greatest influence on the aboveground biomass of the three grassland types (Figure 5B, $R^{2}=0.527$, $p<0.05)$. Moreover, only number density of the rock fragments entered the model when determining which rock fragment parameters exerted the greatest impact on the vegetation diversity (Simpson's index) (Figure 5C, $R^{2}=0.875, p<0.05$ ).

\section{DISCUSSION}

This study found that there was no significant difference in mean shape factor and equivalent diameter among the three grassland types, and the 2-6 $\mathrm{mm}$ rock fragments constituted the largest fraction of rock fragments in the different soil layers for the three vegetation types (Figure 3). Zhongjie et al. (2008) reported that the $2-6 \mathrm{~mm}$ rock fragment content was the highest in the Liupan Mountains in China, and Du et al. (2017) also found that the 2-10 $\mathrm{mm}$ rock fragment content dominated the total volumetric 

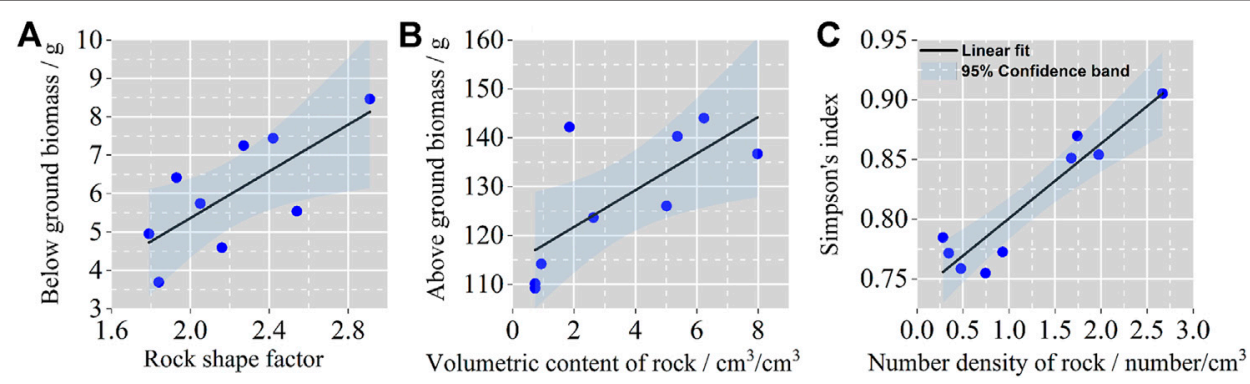

FIGURE 5| Relationship between the belowground biomass, aboveground biomass, Simpson's index and rock fragment characteristics. The black lines indicate the regression fitting lines, and the light blue shaded area indicates the 95\% confidence interval of the regression.

rock fragment content at four topographic positions on a hillslope on the northern Tibetan Plateau. Although the difference among the mean values of the rock fragment characteristics was not statistically significant, the differences in the rock fragment number, number density, volumetric content, and surface area density were significant and followed the order of AM > AS $>$ ADS.

Research has evaluated the effects of rock fragments on the soil properties and plant growth in forest and agricultural systems, and it has been proven that rock fragments impose both positive and negative effects on soil properties and vegetation growth (Heisner et al., 2004; Ercoli et al., 2006; Meersmans et al., 2012; De Baets et al., 2013). Recent studies showed that the coarse fraction of soils (2-4 mm in diameter) contain a considerable stock of available nutrients (Poeplau et al., 2017; Liao et al., 2019), and Koele et al. (2010) suggested that the exchange mechanisms of the short-term nutritional functions in stony soils are in principle the same as those in free fine earth. Smaill et al. (2014) indicated that coarse soil is excluded from conventional soil analysis, and it is possible that the soil nutrient capital is systematically underestimated.

Studies have indicated that the rock fragments in the soil column exert a major effect on the soil $\mathrm{C}$ and $\mathrm{N}$ contents, and the rock fragment content was one of the important limiting factors of the C stock and concentration (Leifeld et al., 2005), while Meersmans et al. (2012) confirmed that the organic carbon concentration in fine earth increased with increasing rock fragment content. Our findings are consistent with those studies, namely, the soil organic carbon, total nitrogen, total phosphorous, avilable phosphorious, $\mathrm{N}-\mathrm{NH}_{4}{ }^{+}$, and $\mathrm{N}-\mathrm{NO}_{3}{ }^{-}$ contents of the fine soils all increased with number density, volumetric content and surface area factor to different degrees, except for total potassium and available potassium (Tables 2, 4; Figure 4). If we consider the nutrient content of the coarse fraction of the soils, the rock fragments may not only reduce the opportunity for the soil to provide nutrients to plants but may in turn also provide favorable conditions for vegetation growth (Danalatos et al., 1995; Heisner et al., 2004; Nie et al., 2021). Alpine ecosystems with stony soils serve as an important carbon pool, and the SOC stock in alpine ecosystems estimated by previous studies has often been based on the fine earth fraction, which may have resulted in underestimate calculations of the soil C stock. An increasing number of studies have suggested that rock fragments are a key factor that should be considered in investigating the stony-soil $\mathrm{C}$ and $\mathrm{N}$ cycles (Wang et al., 2018; Liao et al., 2019).

In our study, positive correlations were observed between the rock shape factor and belowground biomass, while studies indicated negative correlations between the volumetric rock fragment content and bulk density, as well as between bulk density and belowground biomass, which implies that the low bulk density resulting from the high rock fragment content probably strengthened the root penetration ability within fine earth and therefore promoted root growth (van Wesemael et al., 2000). Our results are consistent with those of van Wesemael et al. (2000), as fine earth and rock fragments respond in different ways when expanding and contracting, which may increase the voids between the rock fragments and fine earth, leading to an improved environment for the root system. In addition, we emphasized the role of the rock fragment shape factor. Shape factor of the rock fragments imposed significant positive effects on the soil bulk density, and the stepwise regression results implied that shape factor was the most important factor impacting belowground biomass. Generally, the closer shape factor is to 1 , the closer the shape of the stones is to a sphere, and the larger shape factor is, the more elongated the stones are (Erdogan et al., 2006). The rock fragment shape in AM is more regular and closer to a sphere than that in ADS and AS, while the rock fragments in ADS are more angular, flatter and thinner, and the arrangement is also looser, which probably will also improve the root system environment. For example, Tetegan et al. (2015) and Korboulewsky et al. (2020) both reported that irregular rock fragments could contribute to improving the soil available water content, and these rock fragments in soil even were considered to act as water reservoirs for plants during drought periods.

Moreover, positive correlations were observed between the rock volumetric content and aboveground biomass, number density and Simpson's index (Figure 5). As the organic carbon concentration of the fine soil increased with increasing rock fragment content, the high soil organic carbon content can alter soil compaction and therefore improve the soil structure, which would promote the bonding between primary soil particles, increase soil aeration, improve the quality of soil aggregates (Bronick and Lal, 2005). Moreover, enhance the soil microbial 
activity, and encourage the decomposition of dead animal material and root litter, which in turn would release more organic matter, thereby increasing the capacity of soil to provide nutrients to plants. In addition to improving the nutrient conditions of vegetation, Poesen and Lavee (1994) suggested that small rock fragments are usually more weathered and more porous, and large quantities of water can be absorbed within the soil profile. In our study, we also found that the field capacity of the soil in AM was higher than that of the soil in ADS and AS with a higher rock fragment content (Poesen and Lavee, 1994). These results indicate that soils with a rock fragment content lower than $5 \%$ possess a high water content, which can lead to the prioritization of these soils to maintain thriving plantations, while soils with a high rock fragment content $(>15 \%)$ have a small volume of soil active in water retention. Within a certain range, the increase in rock fragment content is conducive to the storage and circulation of soil water, which contributes to plant growth. In our study, volumetric content of the rock fragments in the soils was $0.80 \pm$ 0.07 (ADS), $3.17 \pm 0.95$ (AS), and $6.53 \pm 0.76$ (AM), well below the $15 \%$ mark, which will have a positive effect on soil moisture retention and storage, and the rock fragments can even be considered a potential reservoir for plants (Tetegan et al., 2015). Furthermore, rock fragments can also change certain features of plants, such as transpiration and water use efficiency (Mi et al., 2016); rock fragments can act as regulators of the soil temperature, and stony soils can warm more rapidly than rock-free soils in seasons with rising temperatures, while when the temperature begins to drop, the stony soil temperature can remain high for a long time (Poesen and Lavee, 1994), which may act as a buffer against the sudden temperature changes that can damage plants and can provide protection for plant root systems, especially in the high-solar radiation environment of this high-altitude alpine region, thus protecting certain vulnerable species and imposing a positive effect on the maintenance of the biological diversity.

\section{CONCLUSION}

There was no significant difference in shape factor and equivalent diameter among the three grassland types, while the differences in number density, volumetric content and surface area density were significant. The contents of soil organic carbon, total nitrogen, total phosphorous, available

\section{REFERENCES}

Allen, D. E., Dalal, R. C., Rennenberg, H., Meyer, R. L., Reeves, S., and Schmidt, S. (2007). Spatial and Temporal Variation of Nitrous Oxide and Methane Flux between Subtropical Mangrove Sediments and the Atmosphere. Soil Biol. Biochem. 39 (2), 622-631. doi:10.1016/j.soilbio. 2006.09.013

Bhattacharyya, R., Prakash, V., Kundu, S., Ghosh, B. N., Srivastva, A. K., and Gupta, H. S. (2006). Potassium Balance as Influenced by Farmyard Manure Application under Continuous Soybean-Wheat Cropping System in a Typic phosphorus, $\mathrm{N}-\mathrm{NH}_{4}{ }^{+}$, and $\mathrm{N}_{-} \mathrm{NO}_{3}{ }^{-}$in the fine soil all increased with increasing number density, volumetric content and surface area density to different degrees. In addition, positive correlations were observed between the rock shape factor and belowground biomass, the rock volumetric content and aboveground biomass, and number density and Simpson's index, suggesting that within a certain range, the increase in rock fragment content is conducive to soil nutrient accumulation and soil water storage and circulation and changes certain features of plants, which contributes to plant growth. Rock fragments should be given more consideration when investigating the relationships between soil and vegetation and its response to climate change in future studies, and more attention is also needed in soil hydrological processes and nutrient cycling modeling studies.

\section{DATA AVAILABILITY STATEMENT}

The original contributions presented in the study are included in the article/Supplementary Material, further inquiries can be directed to the corresponding author.

\section{AUTHOR CONTRIBUTIONS}

YZ: Conceptualization, Methodology, Investigation, Writing-Original Draft. NC: Review and Editing. CaZ and XD: Analyzed the data and draw figures. ChZ: Reviewing and Editing, Supervision.

\section{FUNDING}

This work was supported by the National Key research and Development Program of China (2019YFC0507401), Strategic Priority Research Program of the Chinese Academy of Sciences (XDA20100101), and the National Natural Science Foundation of China (NSFC) (Grant No. 31901364).

\section{ACKNOWLEDGMENTS}

We are grateful to the three reviewers and the Handling Editor for providing insightful comments and suggestions.

Haplaquept. Geoderma 137 (1-2), 155-160. doi:10.1016/j.geoderma.2006. 08.006

Bronick, C. J., and Lal, R. (2005). Manuring and Rotation Effects on Soil Organic Carbon Concentration for Different Aggregate Size Fractions on Two Soils in Northeastern Ohio, USA. Soil Tillage Res. 81 (2), 239-252.

Callow, B., Falcon-Suarez, I., Ahmed, S., and Matter, J. (2018). Assessing the Carbon Sequestration Potential of basalt Using X-ray Micro-CT and Rock Mechanics. Int. J. Greenhouse Gas Control. 70, 146-156. doi:10.1016/j.ijggc. 2017.12.008

Ceacero, C. J., Díaz-Hernández, J. L., Campo, A. D. d., and Navarro-Cerrillo, R. M. (2020). Soil Rock Fragment Is Stronger Driver of Spatio-Temporal Soil Water 
Dynamics and Efficiency of Water Use Than Cultural Management in Holm Oak Plantations. Soil Tillage Res. 197, 104495. doi:10.1016/j.still.2019.104495

Ceacero, C. J., Díaz-Hernández, J. L., del Campo, A. D., and Navarro-Cerrillo, R. M. (2012). Interactions between Soil Gravel Content and Neighboring Vegetation Control Management in Oak Seedling Establishment success in Mediterranean Environments. For. Ecol. Management 271, 10-18. doi:10.1016/j.foreco.2012. 01.044

Chen, H., Liu, J., Wang, K., and Zhang, W. (2011). Spatial Distribution of Rock Fragments on Steep Hillslopes in Karst Region of Northwest Guangxi, China. Catena 84 (1-2), 21-28. doi:10.1016/j.catena.2010.08.012

Comino, J. R., Senciales, J. M., Ramos, M. A., Martínez-Casasnovas, J. A., Lasanta, T., Brevik, E. C., et al. (2017). Understanding soil erosion processes in Mediterranean sloping vineyards (Montes de Málaga, Spain). Geoderma 296, 47-59.

Coppola, A., Dragonetti, G., Comegna, A., Lamaddalena, N., Caushi, B., Haikal, M. A., et al. (2013). Measuring and Modeling Water Content in Stony Soils. Soil Tillage Res. 128, 9-22. doi:10.1016/j.still.2012.10.006

Danalatos, N. G., Kosmas, C. S., Moustakas, N. C., and Yassoglou, N. (1995). Rock Fragments IL Their Impact on Soil Physical Properties and Biomass Production under Mediterranean Conditions. Soil Use Management 11 (3), 121-126. doi:10.1111/j.1475-2743.1995.tb00509.x

De Baets, S., Poesen, J., Knapen, A., Barberá, G. G., and Navarro, J. A. (2007). Root Characteristics of Representative Mediterranean Plant Species and Their Erosion-Reducing Potential during Concentrated Runoff. Plant Soil 294 (12), 169-183. doi:10.1007/s11104-007-9244-2

De Baets, S., Meersmans, J., Vanacker, V., Quine, T. A., and Van Oost, K. (2013). Spatial Variability and Change in Soil Organic Carbon Stocks in Response to Recovery Following Land Abandonment and Erosion in Mountainous Drylands. Soil Use Manage 29 (1), 65-76. doi:10.1111/sum.12017

Du, Z., Cai, Y., Yan, Y., and Wang, X. (2017). Embedded Rock Fragments Affect alpine Steppe Plant Growth, Soil Carbon and Nitrogen in the Northern Tibetan Plateau. Plant Soil 420 (1-2), 79-92. doi:10.1007/s11104-017-3376-9

Ercoli, L., Masoni, A., Mariotti, M., and Arduini, I. (2006). Dry Matter Accumulation and Remobilization of Durum Wheat as Affected by Soil Gravel Content. Cereal Res. Commun. 34 (4), 1299-1306. doi:10.1556/crc.34. 2006.4.272

Erdogan, S. T., Quiroga, P. N., Fowler, D. W., Saleh, H. A., Livingston, R. A., Garboczi, E. J., et al. (2006). Three-dimensional Shape Analysis of Coarse Aggregates: New Techniques for and Preliminary Results on Several Different Coarse Aggregates and Reference Rocks. Cement Concrete Res. 36 (9), 1619-1627. doi:10.1016/j.cemconres.2006.04.003

Estrada-Medina, H., Graham, R. C., Allen, M. F., Jiménez-Osornio, J. J., and Robles-Casolco, S. (2013). The Importance of limestone Bedrock and Dissolution Karst Features on Tree Root Distribution in Northern Yucatán, México. Plant Soil 362 (1-2), 37-50. doi:10.1007/s11104-012-1175-x

Fei (2015). User's Guide Avizo ${ }^{\circledR} 9$.

Heisner, U., Raber, B., and Hildebrand, E. E. (2004). The Importance of the Soil Skeleton for Plant-Available Nutrients in Sites of the Southern Black Forest, Germany. Eur. J. For. Res 123 (4), 249-257. doi:10.1007/s10342-004-0041-7

Helliwell, J. R., Miller, A. J., Whalley, W. R., Mooney, S. J., and Sturrock, C. J. (2014). Quantifying the Impact of Microbes on Soil Structural Development and Behaviour in Wet Soils. Soil Biol. Biochem. 74, 138-147. doi:10.1016/j. soilbio.2014.03.009

Hlaváčiková, H., Holko, L., Danko, M., and Novák, V. (2019). Estimation of Macropore Flow Characteristics in Stony Soils of a Small Mountain Catchment. J. Hydrol. 574, 1176-1187. doi:10.1016/j.jhydrol.2019.05.009

Hlaváčiková, H., Novák, V., and Holko, L. (2015). On the Role of Rock Fragments and Initial Soil Water Content in the Potential Subsurface Runoff Formation. J. Hydrol. Hydromech 63 (1), 71-81. doi:10.1515/johh-2015-0002

Hlaváčiková, H., Novák, V., and Šimůnek, J. (2016). The Effects of Rock Fragment Shapes and Positions on Modeled Hydraulic Conductivities of Stony Soils. Geoderma 281, 39-48. doi:10.1016/j.geoderma.2016.06.034

Hu, X., Li, Z.-C., Li, X.-Y., and Liu, L.-y. (2016). Quantification of Soil Macropores under alpine Vegetation Using Computed Tomography in the Qinghai Lake Watershed, NE Qinghai-Tibet Plateau. Geoderma 264, 244-251. doi:10.1016/j. geoderma.2015.11.001

Ilek, A., Kucza, J., and Witek, W. (2019). Using Undisturbed Soil Samples to Study How Rock Fragments and Soil Macropores Affect the Hydraulic Conductivity of forest Stony Soils: Some Methodological Aspects. J. Hydrol. 570, 132-140. doi:10.1016/j.jhydrol.2018.12.067

Islam, A., Karim, A. J. M. S., Solaiman, A. R. M., Islam, M. S., and Saleque, M. A. (2017). Eight-year Long Potassium Fertilization Effects on Quantity/intensity Relationship of Soil Potassium under Double rice Cropping. Soil Tillage Res. 169, 99-117. doi:10.1016/j.still.2017.02.002

Jackson, M. L. (2005). Soil Chemical Analysis: Advanced Course. U.S.A: UWMadison Libraries Parallel Press. doi:10.1201/noe0849338304.ch343

Koele, N., Hildebrand, E. E., and Schack-Kirchner, H. (2010). Effects of Weathering State of Coarse-Soil Fragments on Tree-Seedling Nutrient Uptake. Z. Pflanzenernähr. Bodenk. 173 (2), 245-251. doi:10.1002/jpln.200800336

Korboulewsky, N., Tetegan, M., Samouelian, A., and Cousin, I. (2020). Plants Use Water in the Pores of Rock Fragments During Drought. Plant Soil 454, 35-47. doi:10.1007/s11104-020-04425-3

Leifeld, J., Bassin, S., and Fuhrer, J. (2005). Carbon Stocks in Swiss Agricultural Soils Predicted by Land-Use, Soil Characteristics, and Altitude. Agric. Ecosyst. Environ. 105, 255-266. doi:10.1016/j.agee.2004.03.006

Li, W., Cao, W., Wang, J., Li, X., Xu, C., and Shi, S. (2017). Effects of Grazing Regime on Vegetation Structure, Productivity, Soil Quality, Carbon and Nitrogen Storage of alpine Meadow on the Qinghai-Tibetan Plateau. Ecol. Eng. 98, 123-133. doi:10.1016/j.ecoleng.2016.10.026

Li, X. Y., Hu, X., Zhang, Z. H., Peng, H. Y., Zhang, S. Y., Li, G. Y., et al. (2013). Shrub Hydropedology: Preferential Water Availability to Deep Soil Layer. Vadose Zone J. 12 (4), 1539-1663. doi:10.2136/vzj2013.01.0006

Liao, K., Lai, X., Zhou, Z., Zeng, X., Xie, W., Castellano, M. J., et al. (2019). Whether the Rock Fragment Content Should Be Considered when Investigating Nitrogen Cycle in Stony Soils? J. Geophys. Res. Biogeosci. 124 (3), 521-536. doi:10.1029/2018jg004780

Ma, D., and Shao, M. (2008). Simulating Infiltration into Stony Soils with a Dual-Porosity Model. Eur. J. For. Res 59 (5), 950-959. doi:10.1111/j.1365-2389.2008.01055.x

Meersmans, J., Martin, M. P., De Ridder, F., Lacarce, E., Wetterlind, J., De Baets, S., et al. (2012). A Novel Soil Organic C Model Using Climate, Soil Type and Management Data at the National Scale in France. Agron. Sustain. Dev. 32 (4), 873-888. doi:10.1007/s13593-012-0085-x

Mi, M., Shao, M. a., and Liu, B. (2016). Effect of Rock Fragments Content on Water Consumption, Biomass and Water-Use Efficiency of Plants under Different Water Conditions. Ecol. Eng. 94, 574-582. doi:10.1016/j.ecoleng.2016.06.044

Nie, X., Wang, D., Yang, L., and Zhou, G. (2021). Controls on Variation of Soil Organic Carbon Concentration in the Shrublands of the Northeastern Tibetan Plateau. Eur. J. Soil Sci., 1-14. doi:10.1111/ejss.13084

Novák, V., and Hlaváčiková, H. (2019). "Stony Soils," in Applied Soil Hydrology (Cham: Springer), 263-282. doi:10.1007/978-3-030-01806-1_17

Poeplau, C., Vos, C., and Don, A. (2017). Soil Organic Carbon Stocks Are Systematically Overestimated by Misuse of the Parameters Bulk Density and Rock Fragment Content. Soil 3 (1), 61-66. doi:10.5194/soil-3-61-2017

Poesen, J., and Lavee, H. (1994). Rock Fragments in Top Soils: Significance and Processes. Catena 23 (1-2), 1-28. doi:10.1016/0341-8162(94)90050-7

Qin, Y., Yi, S., Chen, J., Ren, S., and Ding, Y. (2015). Effects of Gravel on Soil and Vegetation Properties of alpine Grassland on the Qinghai-Tibetan Plateau. Ecol. Eng. 74, 351-355. doi:10.1016/j.ecoleng.2014.10.008

Rabot, E., Wiesmeier, M., Schlüter, S., and Vogel, H.-J. (2018). Soil Structure as an Indicator of Soil Functions: a Review. Geoderma 314, 122-137. doi:10.1016/j. geoderma.2017.11.009

Reyes, F., Lin, Q., Cilliers, J. J., and Neethling, S. J. (2018). Quantifying mineral Liberation by Particle Grade and Surface Exposure Using X-ray microCT. Minerals Eng. 125, 75-82. doi:10.1016/j.mineng.2018.05.028

Sammartino, S., Michel, E., and Capowiez, Y. (2012). A Novel Method to Visualize and Characterize Preferential Flow in Undisturbed Soil Cores by Using Multislice Helical CT. Vadose Zone J. 11 (1). doi:10.2136/vzj2011.0100

Sauer, T. J., and Logsdon, S. D. (2002). Hydraulic and Physical Properties of Stony Soils in a Small Watershed. Soil Sci. Soc. Am. J. 66 (6), 1947-1956. doi:10.2136/sssaj2002.1947

Shen, Y., Yu, Y., Lucas-Borja, M. E., Chen, F., Chen, Q., and Tang, Y. (2020). Change of Soil K, N and P Following forest Restoration in Rock Outcrop Rich Karst Area. Catena 186, 104395. doi:10.1016/j.catena.2019.104395

Smaill, S. J., Clinton, P. W., Allen, R. B., and Davis, M. R. (2014). New Evidence Indicates the Coarse Soil Fraction Is of Greater Relevance to Plant Nutrition Than Previously Suggested. Plant Soil 374 (1-2), 371-379. doi:10.1007/s11104013-1898-3 
Tetegan, M., Korboulewsky, N., Bouthier, A., Samouëlian, A., and Cousin, I. (2015). The Role of Pebbles in the Water Dynamics of a Stony Soil Cultivated with Young Poplars. Plant Soil 391 (1-2), 307-320. doi:10.1007/s11104-015-2429-1

Tetegan, M., Pasquier, C., Besson, A., Nicoullaud, B., Bouthier, A., Bourennane, H., et al. (2012). Field-scale Estimation of the Volume Percentage of Rock Fragments in Stony Soils by Electrical Resistivity. Catena 92, 67-74. doi:10. 1016/j.catena.2011.09.005

van Wesemael, B., Mulligan, M., and Poesen, J. (2000). Spatial Patterns of Soil Water Balance on Intensively Cultivated Hillslopes in a Semi-arid Environment: the Impact of Rock Fragments and Soil Thickness. Hydrol. Process. 14 (10), 1811-1828. doi:10.1002/1099-1085(200007)14:10<1811::aidhyp65>3.0.co;2-d

Wang, D. B., Wang, X. Y., Wu, Y., and Lin, H. L. (2019). Grazing Buffers the Effect of Climate Change on the Species Diversity of Seedlings in an alpine Meadow on the Tibetan Plateau. Ecol. Evol. 9 (3), 1119-1126. doi:10.1002/ece3.4799

Wang, K., and Zhang, R. (2011). Heterogeneous Soil Water Flow and Macropores Described with Combined Tracers of Dye and Iodine. J. Hydrol. 397 (1-2), 105-117. doi:10.1016/j.jhydrol.2010.11.037

Wang, X., Yoo, K., Wackett, A. A., Gutknecht, J., Amundson, R., and Heimsath, A. (2018). Soil Organic Carbon and mineral Interactions on Climatically Different Hillslopes. Geoderma 322, 71-80. doi:10.1016/j.geoderma.2018.02.021

Wildenschild, D., and Sheppard, A. P. (2013). X-ray Imaging and Analysis Techniques for Quantifying Pore-Scale Structure and Processes in Subsurface Porous Medium Systems. Adv. Water Resour. 51, 217-246. doi:10.1016/j.advwatres.2012.07.018

Wilson, M. G., Sasal, M. C., and Caviglia, O. P. (2013). Critical Bulk Density for a Mollisol and a Vertisol Using Least Limiting Water Range:. Geoderma 192, 354-361. doi:10.1016/j.geoderma.2012.05.021

Xu, G., Chao, Z., Wang, S., Hu, Y., Zhang, Z., Duan, J., et al. (2010). Temperature Sensitivity of Nutrient Release from Dung along Elevation Gradient on the Qinghai-Tibetan Plateau. Nutr. Cycl Agroecosyst 87 (1), 49-57. doi:10.1007/ s10705-009-9311-6

Yunfei, G., Chuanyan, Z., Zhanlei, R., Junjie, L., Qingtao, W., Lijuan, G., et al. (2019). Energy Exchange between the Atmosphere and a Subalpine Meadow in the Qilian Mountains, Northwest China. J. Hydrol. 572, 771-780. doi:10.1016/j. jhydrol.2019.01.069

Zhang, T., Zhou, X. P., and Liu, X. F. (2020). Reliability Analysis of Slopes Using the Improved Stochastic Response Surface Methods with Multicollinearity. Eng. Geology. 271, 105617. doi:10.1016/j.enggeo.2020.105617

Zhang, Y., Zhang, M., Niu, J., Li, H., Xiao, R., Zheng, H., et al. (2016a). Rock Fragments and Soil Hydrological Processes: Significance and Progress. Catena 147, 153-166. doi:10.1016/j.catena.2016.07.012

Zhang, Z., Lin, L., Wang, Y., and Peng, X. (2016b). Temporal Change in Soil Macropores Measured Using Tension Infiltrometer under Different Land Uses and Slope Positions in Subtropical China. J. Soils Sediments 16 (3), 854-863. doi:10.1007/s11368-015-1295-Z

Zhen, Q., Ma, W., Li, M., He, H., Zhang, X., and Wang, Y. (2017). Reprint of "Effects of Vegetation and Physicochemical Properties on Solute Transport in Reclaimed Soil at an Opencast Coal Mine Site on the Loess Plateau, China”. Catena 148, 17-25. doi:10.1016/j.catena.2016.09.012

Zhongjie, S., Yanhui, W., Pengtao, Y., Lihong, X., Wei, X., and Hao, G. (2008) Effect of Rock Fragments on the Percolation and Evaporation of forest Soil in Liupan Mountains, China. Acta Ecologica Sinica 28 (12), 6090-6098. doi:10. 1016/s1872-2032(09)60014-7

Zhou, B. B., Shao, M. A., Wang, Q. J., and Yang, T. (2011). Effects of Different Rock Fragment Contents and Sizes on Solute Transport in Soil Columns. Vadose Zone J. 10 (1), 386-393. doi:10.2136/vzj2009.0195

Conflict of Interest: The authors declare that the research was conducted in the absence of any commercial or financial relationships that could be construed as a potential conflict of interest.

Copyright (c) 2021 Zheng, Chen, Zhang, Dong and Zhao. This is an open-access article distributed under the terms of the Creative Commons Attribution License (CC $B Y)$. The use, distribution or reproduction in other forums is permitted, provided the original author(s) and the copyright owner(s) are credited and that the original publication in this journal is cited, in accordance with accepted academic practice. No use, distribution or reproduction is permitted which does not comply with these terms. 